\title{
Father Joseph Lelarge de Lignac, a French Oratorian and a Friend of Reaumur against Buffon
}

\begin{abstract}
Olivier Perru
Université Lyon 1

Father Joseph-Adrien Lelarge de Lignac was born in Poitiers (France) in the year 1697. He died in Paris in 1762. In 1731, he was ordained priest and he became an oratorian the following year. His Letters to an American is an attempt to refute Buffon and Condillac; this book was prepared in collaboration with Réaumur (J. Roger, P. Charbonnat). Here, we present some elements of the correspondence between Lignac and Réaumur which show a scientific dialogue about 1736-1748 and we try to bring some foundations of the thought of Lignac to light. Between empiricism and ontology, Lignac stands up for scientific questions being subject to literal reading of the Bible. But Lignac is also the first one to perceive a way of thinking in Buffon Natural History (T. Hoquet). According to him, the thought of Buffon is a deviation in an order of knowledge, because Natural History would especially be based on observation and experiment. So in this paper, we emphasize two original sources in the thought of Father de Lignac: Malebranche philosophy and his collaboration with Réaumur.

Keywords: Réaumur, Buffon, Malebranche, Ontology, Empiricism, Natural History
\end{abstract}

\section{Introduction}

In 1697, Joseph-Adrien Lelarge de Lignac was born in Poitiers. He died in Paris, in the year $1762 .^{1}$ He learnt humanities in Paris (1705-1712), then rhetoric and philosophy in Poitiers. Having studied law and theology, he was ordained as a priest in 1731; he became an Oratorian in 1732. He taught in a college in Le Mans; he was superior of the college of Nantes (1743-1746). He stayed twice in Saumur (1741-1743 and 1746-1752) to write his works. In 1754, he was expelled from the Oratorians; he lived in Paris until 1762.

During 18 months, under the reign of Pope Benedict XIV, he stayed in Rome. He was welcomed by Benedict XIV and cardinal Passionei. He took part to some talks with Passionei in Frascati, "where piety, freedom, spirit were delighted” (Le Goff 1863, VIII). ${ }^{2}$ Later, De Lignac dedicated his book against Helvetius to Passionei. In Turin, he encountered cardinal des Lances and Gerdil who dedicated to him Defense of the Opinion of Malebranche about the Nature and Origin of the Ideas against Locke. Cardinal des Lances was frightened of the enlightenment. According to him, Lignac seems to have been chosen to defend the Church against its enemies.

The Letters to an American tries to refute Buffon's ideas. Jacques Roger wrote: "Since 1749, he has been become a close friend of Reaumur and he was his guest during holidays in Poitou, from the beginning of

Olivier Perru, professor in History and Philosophy of Sciences; Sciences, Société, Historicité, Education, Pratiques, E.A. 4148 S2HEP, Université Lyon 1 and ENS-Lyon, France; main research field: History and Philosophy of Biology, Philosophy of the Living, Science and Religion. Email: olivier.perru@univ-lyon1.fr. 
September to All Saints' Day. So, we believe that a first project of the Letters arose in the summer of 1749, when Reaumur and Buffon observed together Tremblays's polyp. This idea seduced Reaumur” (Roger 1993, 691). So the talks between Reaumur and Lignac began in 1745. Their scientific relations existed in 1736 and became very strong in 1743-1744. During the holidays in 1751, Reaumur did again Needham's observations with Lignac and Brisson as assistants. We don't know how Reaumur participated to the three first books, which may be collaborating to the redaction, or writing some notes. He recommended Letters to an American to his readers.

Father de Lignac wrote some papers in metaphysics, theology, and natural history. He practiced natural history. He was a good example of the period after 1750, because he was involved in a real war against the enlightenment.

\section{The Correspondence between Lignac and Reaumur (1736-1748) ${ }^{3}$}

These Letters are interesting because they illustrate the friendly and scientific relation between with the author of the Memoirs for the History of Insects. Lignac is a naturalist and a philosopher. Reaumur is the catholic scientist and he is an opponent to Buffon. With Reaumur and Lignac, the symbol of the true science against the wrong science already works.

On July 29th 1736, a Letter from Lignac to Reaumur clearly shows a Christian attitude and a naturalist way of thinking, deeply rooted in Malebranche philosophy. The study of Nature and a conversion to God work together. He writes:

Your Mémoires pour servir à l'histoire des insectes have cured my mistakes... You extremely enlarged my world. And the novelty of the sight you offer more easily turns me to God than do these immense bodies. We had no resource when we imagined that insects may be an effect of corruption. What madness! Are we so far from the same origin if we assert that so complex machines are randomly made up? These machines regularly present so extraordinary metamorphoses! We often question how useful were so many different insects. Your book teaches us they are used for admiration of the Creator. (Lelarge de Lignac 1736)

Here, the theme is apologetic; insects illustrate creative activity of God. "Our Father Malebranche seduced me by some figures of the Resurrection that he found in insects' metamorphoses. But since I saw these wonders myself, I was disenchanted. I don't even know how this great man had not understood that butterflies are not enough likely to show risen bodies.” It's a frequent theme at the time; metamorphosis of insects may be seen as a sign of resurrection. Lignac shows us that the progresses in insects' description don't allow making this language. From Malebranche to Pluche and to the jansenist poet Louis Racine, this naturalist symbolic representation is very frequent during the first half of the 18th century. In his book (Memoirs for the History of Insects), Reaumur quotes: "Father de Lignac who is able to do some comments about subjects less noticeable than insects, capable of doing the most abstracts conjectures in metaphysics (Reaumur 1736, XLIII).”

On 8th February 1744, Lignac said that he had intention of going to Reaumur during the holidays. It is a confirmation that Lignac was a guest of Reaumur, during the summer, before 1749 (contrary to Jacques Roger who told us that he came the first time to Reaumur in the year 1749).

On last holidays, I found it impossible to go to Reaumur. But during this year, I hope to be honored with seeing you there. My Memoires are in the hands of M. de Montcarville who is the beautiful invisible man according to Père de La Borde. He tried three times to boost him, but without any success. Could you do something with this fearsome censor? (Lelarge de Lignac 1744) 
Here, he talked about the publication of the Memoir on the Aquatic Spiders. Then, abbé de Lignac explains how he collected aquatic insects in the river Erdre which crosses Nantes. At this time, he was the superior in the college of Nantes; he carried on his works on insects. These works were not much edited.

From 1745, the controversy on polyps appeared in the letters. Abraham Trembley (1710-1784) just published his report for history of a kind of aquatic polyp. Reaumur was corresponding with him too. Lignac described the polyps' budding. He probably did again Trembley's experiment, which may be with Reaumur:

From this double skin that belongs to the mother, some arms come out. So, we call this organism a new polyp. Its stomach is the same as the stomach of the other polyp. Each one is fed on one side but digestion is mutual. At last there is a neck; the part of common skin to the two alleged animals is separated from the first. And so these two animals are perfect! In fact is this phenomenon a process to produce an animal? (Lelarge de Lignac 1745)

There is a polemic about polyps. According to Father de Lignac or to Dom Allou, polyp is a plant rather than an animal. It may not be an intermediary being because in the Bible, God creates plants and animals in diverse times. Lignac carries on: "Let you remember the ingenious way to double a first polyp with a second one. The first one can't eat. The second one eats and the juice is shared out among the two animals; the food's color is visible outside. The two polyps show the juice's color and digestive canals remain invisible" (Lelarge de Lignac 1745). Lignac tries to express the phenomenon of budding but he is very perplexed about these living beings. According to Lelarge de Lignac, we practically cannot consider the polyp as a lonely animal. On January 31th 1748, he reproached Reaumur for the distribution of a report he wrote on polyps. This report disappeared.

\section{Method and Polemic}

Father Lelarge de Lignac was not well-known during the 18th century. His books remain unknown. One hundred years later, François Le Goff wrote: “Abbé de Lignac was destined for remaining unknown. In spite of the famous name of his opponent, the first among his philosophical essays, Letters to an American about General and Particular Natural History of M. de Buffon, passed completely unnoticed in France” (Le Goff 1863, V). According to François Le Goff, the intention of Lignac was to assert solidarity between reason and faith, in the spirit of "the Oratory." De Lignac was scandalized by the materialism of Buffon, described as the "anti-Polignac.” So, he attacked him in the Letters to an American. Lignac's work asks about the action of God Creator and about nature. Is nature an object of experiment or a concept in a philosophical system: This is the question of Lignac against Buffon.

Thierry Hoquet writes:

A physics of general effects, as Buffon attempts to describe it, can't give a role to God, as a First Cause. Does Epicureanism (rejecting final causes) necessary drive the humans to atheism (rejecting first cause)? Lelarge de Lignac asks the question and considers Buffon as the "anti-Polignac". If Buffon makes oneself known as the exact contrary of cardinal Melchior de Polignac (1661-1741) who wrote the Anti-Lucrèce, he is himself a new Lucrèce and the Histoire naturelle is joined to Epicureanism by the reduction from moral to physical world. (Hoquet 2005, 487)

If Lelarge de Lignac asks the question of a role played by the Creator in philosophical systems of the Enlightenment, particularly in Buffon's system, the reason is that he is deeply rooted in Malebranche thought. In the extreme consequences of Malebranche philosophy thought by Lignac, each one can experience that his spiritual being is immortal and created by God. "I feel that I exist thanks to a whole powerful cause of which I know the will as an infinitely productive will” (Lelarge de Lignac 1753, 34). 
"An indestructible being made up on the occasion of a body (the occasional cause of Malebranche) has not been made to be destroyed on the occasion of the disappearance of this same body" (Lelarge de Lignac 1753, 452).

\title{
4. Conclusion
}

Pascal Charbonnat underlines a paradox in the thought of Lignac: on one side, research for empirical proofs; on the other side, metaphysical thought allowing an immaterial substance to exist. This is a problem during the 18th century. Empiricism in new sciences calls for a revival of metaphysics. This revival would imply a whole demonstration based on experience. Joseph-Adrien Lelarge de Lignac has doubtless understood this necessity of experience and empirical proof in metaphysics. However, what is experience and demonstration in metaphysics?

Lelarge de Lignac insisted on sensitive and individual experience in order to demonstrate the existence of the soul. Beyond the soul, a metaphysical thought tries to establish the existence of a primary cause. So, Lelarge de Lignac should transform the philosophy of Malebranche in a sensualism. Pascal Charbonnat writes:

Lignac doesn't use the act of creation as an argument because he should be on a metaphysical side, by definition beyond an empirical criterion. He is only searching for actual expressions of transcendence, an immaterial substance inside the individuals. He thinks that this substance may be related to a sensitive experience. Abbé de Lignac... proposes a theory of the soul reconciled with the criterion of empirical validity... But he didn’t succeed. (Charbonnat 2010, 90)

Come back to the empirical and mechanistic method used by the authors of the 18th century when they tried to understand nature and universe. In the works of Buffon, a physical reduction excludes God in the explanation of the universe. Buffon makes a distinction between a scientific explanation of the world and the biblical viewpoint. During the 18th century, it was incomprehensible: Lignac goes from a literal reading of the Bible to scientific issues and reciprocally, without any problem. Buffon seems to build a system in order to describe and to explain the nature. It was very different from contemporary Natural History. Lignac considers Natural History of Buffon as a system, whereas this knowledge should be based on observation and experiment.

\section{Notes}

\author{
1. Auvray, 1975. \\ 2. The author of this paper translated into English all French quoted texts. \\ 3. Perru, 2012.
}

\section{Works Cited}

Auvray, Paul. “Joseph-Adrien Lelarge de Lignac.” Catholicisme, VII. Paris: Letouzey, 1975. 774-5.

Charbonnat, Pascal. When Sciences Have a Dialogue with Metaphysics. Paris: Vuibert, 2010.

Ferchault, de Réaumur René-Antoine. Memoirs for the History of Insects, II. Paris: Imprimerie Royale, 1736 (in French).

Hoquet, Thierry. Buffon: Natural History and Philosophy. Paris: Honoré Champion, 2005 (in French).

Le Goff, François. About the Philosophy of Abbé de Lignac. Paris: Hachette, 1863 (in French).

Lelarge de Lignac Joseph-Adrien. "Letter to Réaumur of July 29th, 1736.” Fonds Réaumur, 66/84, R.12.11. Paris: Archives de l’Académie des Sciences, 1736 (in French).

---. “Letter to Réaumur of July 3th, 1745.” Fonds Réaumur, 66/84, R.12.14. Paris: Archives de l’Académie des Sciences, 1745 (in French). 
---. “Letter to Réaumur of February 29th, 1744.” Fonds Réaumur, 66/84, R.12.14. Paris: Archives de l’Académie des Sciences, 1744 (in French).

---. Elements of Metaphysics Learned from the Experience or Letters to a Materialist on the Nature of Soul. Paris: Desaint et Saillant, 1753 (in French).

Perru Olivier. Clergymen and Science during the 18th Century: Towards a Harmony between Reason, Nature and Creation. Paris: Vrin, 2012. (Book in French. French title: Hommes d'Eglise et Science au XVIIIe siècle: Vers une harmonie entre Raison, Nature et Création).

Roger Jacques. Life Sciences in the French Thought in the 18th Century. Paris: Albin Michel, 1993. (Book in French. French title: Les sciences de la vie dans la pensée française au 18 e siècle). 